\title{
Preservation of a Preglacial Landscape Under the Center of the Greenland Ice Sheet
}

\author{
Paul R. Bierman, ${ }^{1 *}$ Lee B. Corbett, ${ }^{1}$ Joseph A. Graly ${ }^{1} \dagger$ Thomas A. \\ Neumann, ${ }^{1} \ddagger$ Andrea Lini, ${ }^{1}$ Benjamin T. Crosby, ${ }^{2}$ Dylan H. Rood ${ }^{3,4} \S$
}

${ }^{1}$ Department of Geology and Rubenstein School of the Environment and Natural Resources, University of Vermont, Burlington, VT 05405, USA. ${ }^{2}$ Department of Geosciences, Idaho State University, Pocatello, ID 83209, USA. ${ }^{3}$ Earth Research Institute, University of California, Santa Barbara, CA 93016, USA. ${ }^{4}$ Center for Accelerator Mass Spectrometry, Lawrence Livermore National Laboratory, Livermore, CA 94550, USA.

${ }^{*}$ Corresponding author. E-mail: pbierman@uvm.edu

†Present address: Department of Geology and Geophysics, University of Wyoming, Laramie, WY 82071, USA.

¥Present address: Cryospheric Sciences Laboratory, NASA Goddard Space Flight Center, Greenbelt, MD 20771, USA.

§Present address: Scottish Universities Environmental Research Centre, University of Glasgow, East Kilbride G75 0QF, UK.

Continental ice sheets typically sculpt landscapes via erosion; under certain conditions, ancient landscapes can be preserved beneath ice and can survive extensive and repeated glaciation. We used concentrations of atmospherically produced cosmogenic beryllium-10, carbon, and nitrogen to show that ancient soil has been preserved in basal ice for millions of years at the center of the ice sheet at Summit, Greenland. This finding suggests ice sheet stability through the Pleistocene (i.e., the past 2.7 million years). The preservation of this soil implies that the ice has been non-erosive and frozen to the bed for much of that time, that there was no substantial exposure of central Greenland once the ice sheet became fully established, and that preglacial landscapes can remain preserved for long periods under continental ice sheets.

A diverse set of geochemical records has been developed from ice recovered in the 3054-m Greenland Ice Sheet Project 2 (GISP2) core. These data provide a detailed history of climate and ice dynamics stretching back over 100,000 years. The lowermost $13 \mathrm{~m}$ of the core, which contain high concentrations of sediment, are less well studied. Here, we used measurements of atmospherically produced (meteoric) ${ }^{10} \mathrm{Be}$, carbon, and nitrogen in sediment extracted from this silty ice zone to better understand the source and age of this material and to infer the erosional and thermal history under the center of the Greenland Ice Sheet (GIS) since its inception millions of years ago.

Ice likely was present on Greenland starting $~ 38$ million years ago (Ma), expanding after $14 \mathrm{Ma}$ with glaciations becoming more frequent after $\sim 7 \mathrm{Ma}$ and full coverage of Greenland by ice occurring at $\sim 2.7 \mathrm{Ma}$ $(1,2)$. Fossils in north Greenland suggest a partially forested tundra landscape some time before the growth of the current ice sheet (3). The more recent history of the GIS (the past 100,000 years) is constrained by ice cores as well as geologic mapping (4), cosmogenic nuclides (5), geochemical proxies (6), sea level records (7), and ${ }^{14} \mathrm{C}$ dating of sediment (8).

Glacial erosion rates are controlled by thermal conditions at the bed. Ice colder than the pressure melting point is frozen to the bed (coldbased) and non-erosive. Ice warmer than the pressure melting point (warm-based) can erode the bed. Using heat-flux data, one model suggests that $>75 \%$ of the present GIS is warm-based and thus erosive (9); however, the present-day thermal state of the GIS is known with certainty only where drilling exposes the bed.
The rate at which the GIS erodes its bed and the spatial distribution of subice erosion are uncertain. North Atlantic sediment volume estimates suggest that, on average, $\sim 100 \mathrm{~m}$ of rock were removed from glaciated areas of North America and Greenland after sustained glaciation began at $2.7 \mathrm{Ma}(10)$. This corresponds to an average erosion rate of $\sim 40 \mathrm{~m}$ per million years-a value that masks variability over space and time.

All GIS cores that have been drilled to or near to the bed contain silty basal ice (11). This ice can contain organic material (12), microorganisms, and high gas concentrations (13) and can display a stable water isotope signature (14) interpreted as indicating warmer conditions when the basal ice formed (11), perhaps in the absence of an ice sheet (15).

At the bottom of the GISP2 ice core (Summit, Greenland; Fig. 1), $13 \mathrm{~m}$ of silty ice [average $0.4 \%$ solids (16)] overlies $48 \mathrm{~cm}$ of diamict containing erratic lithologies and underlain by granitic rock $(11,16,17)$. The basal ice has not been dated directly, but the composition of dissolved gases suggests an age of at least 237,000 years (18). Ice at Summit is currently frozen to the bed $\left(-9^{\circ} \mathrm{C}, 6^{\circ} \mathrm{C}\right.$ below the pressure melting point) (19), and models suggest that it has remained frozen to the bed for at least the last several glacial cycles (20).

To understand the origin and history of the sediment in basal GISP2 ice, we measured the concentration of meteoric ${ }^{10} \mathrm{Be}$ adhered to sand and silt extracted from 17 samples of GISP2 silty ice. This isotope is continuously produced by cosmic rays in the atmosphere, is delivered to Earth's surface by precipitation and dry fall, and adheres to sediment. It has been used to date soils and infer erosion rates (21). We also measured organic carbon (OC) and total nitrogen (TN) in these same samples. To provide an analog for the GIS data, we measured a meteoric ${ }^{10} \mathrm{Be}$ profile in a permafrost tundra soil developed on a mid-Pleistocene glacial surface in Alaska (22). Methodological details and data tables are provided in the supplementary materials.

All silty ice sediment samples contained high concentrations of meteoric ${ }^{10} \mathrm{Be}$ and detectable levels of OC and TN (Fig. 2). Sediment in an $11-\mathrm{cm}$ sample of ice just above the bed had the highest concentration of meteoric ${ }^{10} \mathrm{Be}\left(3.8 \times 10^{8}\right.$ atoms $\left.\mathrm{g}^{-1}\right)$. Other sediment samples contained $0.61 \times 10^{8}$ to $1.02 \times 10^{8}$ atoms meteoric ${ }^{10} \mathrm{Be} \mathrm{g}^{-1}$. In general, we found that ${ }^{10} \mathrm{Be}$ and $\mathrm{OC}$ concentrations decrease with sample distance above the bed. This decrease is consistent with the mixing of two components: (i) locally eroded soil material with both high meteoric ${ }^{10} \mathrm{Be}$ and $\mathrm{OC}$ concentrations, and (ii) eroded rock or sediment containing little meteoric ${ }^{10} \mathrm{Be}$ or OC. The second component could be rock flour derived from outcrop abrasion or till sourced from below the depth to which meteoric ${ }^{10} \mathrm{Be}$ has penetrated soil, regolith, and rock.

The geochemical data suggest that sediment incorporated into the silty ice zone was derived from erosion of a stable cold-region landscape. ${ }^{10} \mathrm{Be}$ concentrations measured in silty ice sediment are similar to those 
measured in long-lived soils (21). Compared to $541{ }^{10} \mathrm{Be}$ concentrations measured in soil $(21)$, the maximum ${ }^{10} \mathrm{Be}$ concentration measured in GISP2 sediment ranks in the 60th percentile (Fig. 3A). Sediment extracted from GISP2 silty ice contains 0.3 to $1.7 \%$ OC and 0.03 to $0.14 \%$ $\mathrm{TN}$. The $\mathrm{OC} / \mathrm{TN}$ regression indicates a $\mathrm{C} / \mathrm{N}$ ratio of $\sim 10$, consistent with values reported for mineral-rich subsoils from boreal regions and cryoturbated tundra $(23,24)$. Both OC and TN concentrations are positively correlated with ${ }^{10} \mathrm{Be}$ concentration and all decrease above the bed, indicating that ${ }^{10} \mathrm{Be}, \mathrm{C}$, and $\mathrm{N}$ are derived from the same source, most likely a former tundra soil.

We can estimate the inventory of meteoric ${ }^{10} \mathrm{Be}$ in the soil before burial beneath the GIS. Such a calculation is viable because soil generally retains ${ }^{10} \mathrm{Be}$ and because ${ }^{10} \mathrm{Be}$ soil inventories-at least in temperate regions where sufficient data exist to make this comparison-are well correlated on a global scale with the maximum measured concentration of ${ }^{10} \mathrm{Be}$ in the soil profile (Fig. 3B) (21). Taking the maximum measured meteoric ${ }^{10} \mathrm{Be}$ concentration $\left(3.8 \times 10^{8}\right.$ atoms $\left.\mathrm{g}^{-1}\right)$ at face value suggests an inventory of $6.7 \times 10^{10}$ atoms meteoric ${ }^{10} \mathrm{Be} \mathrm{cm}^{-2}$ (Fig. 3B). However, if we presume that the soil from which the silty ice was derived predates the GIS and is thus older than 2.7 million years $\left(\sim 2\right.$ half-lives of $\left.{ }^{10} \mathrm{Be}\right)$, then the concentration when the soil was first buried by ice, after correcting for radioactive decay of ${ }^{10} \mathrm{Be}$, was higher by a factor of more than 4 $\left(\sim 1.5 \times 10^{9}\right.$ atoms meteoric $\left.{ }^{10} \mathrm{Be}^{-1}\right)$. The corresponding soil inventory when the GIS developed was $\sim 3.8 \times 10^{11}$ atoms meteoric ${ }^{10} \mathrm{Be} \mathrm{cm}^{-2}$. Such concentrations and inventories, while high, are reasonable. The tundra soil from the North Slope of Alaska, developed on a till plain that has been stable for between 150,000 and 750,000 years (22), contains up to $1.1 \times 10^{9}$ atoms meteoric ${ }^{10} \mathrm{Be} \mathrm{g}^{-1}$ and has an inventory of $4.0 \times 10^{10}$ atoms meteoric ${ }^{10} \mathrm{Be} \mathrm{cm}^{-2}$, consistent with the meteoric ${ }^{10} \mathrm{Be}$ concentrations in the silty ice zone and the inferred meteoric ${ }^{10} \mathrm{Be}$ inventory (Fig. 4).

The duration over which this ancient soil developed in Greenland before expansion of the GIS can be roughly estimated using the delivery rate of meteoric ${ }^{10} \mathrm{Be}$ to the GISP2 site $\left[3.5 \times 10^{5}\right.$ atoms cm ${ }^{-2}$ year ${ }^{-1}$ in the upper, silt-free ice of the GISP 2 core (25)]. With no erosion and assuming the Holocene meteoric ${ }^{10} \mathrm{Be}$ deposition rate, the soil material in the silty ice zone was subaerially exposed for at least 200,000 years (no decay correction) and perhaps more than 1 million years (decaycorrected). Even using a deposition rate several times higher, assuming a weakened polar vortex and increased precipitation during past warm periods, the soil incorporated in GISP2 basal silty ice requires far longer exposure (on the order of $10^{5}$ years) than can be accounted for by a few millennium-long periods of exposure during extreme interglacials [such as marine isotope stage (MIS) 11]. Therefore, the data are most consistent with soil formation prior to the existence of the present GIS. On the basis of similarly high meteoric ${ }^{10} \mathrm{Be}$ concentrations, ancient preglacial regolith has been identified on uplands and in glacial sediments preserved on Baffin Island in arctic Canada (26).

Other means of generating high meteoric ${ }^{10} \mathrm{Be}$ concentrations in sediment extracted from the GISP2 silty ice zone do not appear plausible. It is unlikely that the ${ }^{10} \mathrm{Be}$ we measured was concentrated from basal meltwater. Ice in the GISP2 core contains on average $1.4 \times 10^{4}$ atoms meteoric ${ }^{10} \mathrm{Be}^{-1}$ (25), four orders of magnitude less than measured in the silty ice. Stable water isotope data from basal ice of the nearby Greenland Ice Core Project (GRIP) core (19) fall on the meteoric water line and are inconsistent with large-scale melting that would be needed to concentrate ${ }^{10} \mathrm{Be}$. The positive, linear correlation between $\mathrm{OC}$ and ${ }^{10} \mathrm{Be}$ (Fig. 2) is also inconsistent with delivery of meteoric ${ }^{10} \mathrm{Be}$ from meltwater. Long and/or warm interglacials (MIS 5e, 9, and 11) are unlikely to have melted the entire GIS, and even if they did, the peak of each interglacial is so short (thousands of years) that insufficient meteoric ${ }^{10} \mathrm{Be}$ would be delivered to any exposed soil at Summit to build up even a few percent of the meteoric ${ }^{10} \mathrm{Be}$ inventory we infer. On the basis of the marine isotope record (27), other interglacials were less intense than MIS 5e, 9, and 11 and thus even less likely to melt the entire GIS. In situ production of ${ }^{10} \mathrm{Be}$ by the interaction of cosmic rays (specifically muons) with sediment under the ice sheet, which is several kilometers thick, generates an inventory of only a few atoms ${ }^{10} \mathrm{Be}^{-1}$ over a period of 2.7 million years $(28)$.

Previous but imprecise measurements of in situ ${ }^{10} \mathrm{Be},{ }^{26} \mathrm{Al}$, and ${ }^{36} \mathrm{Cl}$ in rock collected below the silty ice zone of the GISP2 core are consistent with short exposure of that rock (at most a few thousand years) around $0.5 \pm 0.2 \mathrm{Ma}$, possibly during the long MIS 11 interglaciation (29). If there were a short period of exposure during MIS 11, then the pre-Pleistocene soil below GISP2 was not fully eroded during that exposure. Any in situ produced ${ }^{10} \mathrm{Be},{ }^{26} \mathrm{Al}$, and ${ }^{36} \mathrm{Cl}$ accumulated in rock during brief exposure at MIS 11 could have been produced under a cover of uneroded, pre-Pleistocene soil, or the soil we sampled could have been transported from nearby. The ${ }^{10} \mathrm{Be}$ measurements presented here demand a much longer period of subaerial exposure than the data of Nishiizumi et al. (29), many tens to a few hundreds of thousands of years, a duration of exposure only possible at Summit before the expansion of the GIS at $\sim 2.7 \mathrm{Ma}$.

The continued presence of soil in GISP2 ice for several million years after formation of the GIS indicates extremely low rates of sub-ice erosion and slow rates of horizontal ice advection away from Summit. Such low shear rates are consistent with both long-term stability of the GIS ice divide location and a frozen bed for most, if not all, of the past 2.7 million years. The existence of ancient soil implies low sub-ice erosion rates; however, the 13-m thickness of the silty ice zone suggests erosion, entrainment, and mixing of the preglacial soil. Although persistence of this ancient soil precludes substantial erosion at the bed (16), it is possible that cold-based ice incorporated some basal debris (30). The flux of silty ice past the GISP2 site is likely dominated by deformation within the ice rather than by sliding (11). If warm-based ice was present at Summit for short periods of time in the past, it did little more than mix sediment from the bed into the overlying ice.

Meteoric ${ }^{10} \mathrm{Be}$ data constrain both the preglacial landscape history and the Quaternary history of Summit, Greenland. ${ }^{10} \mathrm{Be}$ and OC data are consistent with inferences, based on the stable oxygen isotopic composition of ice and the concentration and isotopic composition of gases in the silty ice zone, that the GIS overran a local snowfield or ice that itself overlay a soil (13). Since the GIS formed, the soil has been preserved and only slowly eroded, implying that an ancient landscape underlies $3000 \mathrm{~m}$ of ice at Summit. These new data are most consistent with continuous cover of Summit by ice for the entire Quaternary, with at most brief exposure and minimal surface erosion during the warmest or longest interglacials.

\section{References and Notes}

1. J. S. Eldrett, I. C. Harding, P. A. Wilson, E. Butler, A. P. Roberts, Continental ice in Greenland during the Eocene and Oligocene. Nature 446, 176-179 (2007). doi:10.1038/nature05591 Medline

2. H. C. Larsen, A. D. Saunders, P. D. Clift, J. Beget, W. Wei, S. Spezzaferri, ODP Leg 152 Scientific Party, Seven million years of glaciation in Greenland. Science 264, 952-955 (1994). doi:10.1126/science.264.5161.952 Medline

3. S. Funder, N. Abrahamsen, O. Bennike, R. W. Feyling-Hanssen, Forested arctic: Evidence from North Greenland. Geology 13, 542 (1985). doi:10.1130/0091-7613(1985)13<542:FAEFNG > 2.0.CO;2

4. D. Winkelmann, W. Jokat, L. Jensen, H.-W. Schenke, Submarine end moraines on the continental shelf off NE Greenland: Implications for Lateglacial

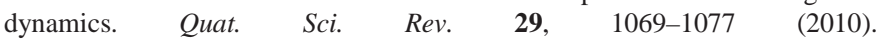
doi:10.1016/j.quascirev.2010.02.002

5. L. Håkansson, J. P. Briner, A. Aldahan, G. Possnert, ${ }^{10} \mathrm{Be}$ data from meltwater channels suggest that Jameson Land, east Greenland, was ice-covered during the last glacial maximum. Quat. Res. 76, 452-459 (2011). doi:10.1016/j.yqres.2011.06.007 
6. A. E. Carlson, J. S. Stoner, J. P. Donnelly, C. Hillaire-Marcel, Response of the southern Greenland Ice Sheet during the last two deglaciations. Geology 36, 359 (2008). doi:10.1130/G24519A.1

7. A. J. Long, D. H. Roberts, M. J. R. Simpson, S. Dawson, G. A. Milne, P. Huybrechts, Late Weichselian relative sea-level changes and ice sheet history in southeast Greenland. Earth Planet. Sci. Lett. 272, 8-18 (2008). doi:10.1016/j.epsl.2008.03.042

8. H. Cremer, O. Bennike, B. Wagner, Lake sediment evidence for the last deglaciation of eastern Greenland. Quat. Sci. Rev. 27, 312-319 (2008). doi:10.1016/j.quascirev.2007.09.004

9. R. Greve, Relation of measured basal temperatures and the spatial distribution of the geothermal heat flux for the Greenland ice sheet. Ann. Glaciol. 42, 424-432 (2005). doi:10.3189/172756405781812510

10. E. P. Laine, New evidence from beneath the Western North Atlantic for the depth of glacial erosion in Greenland and North America. Quat. Res. 14, 188 198 (1980). doi:10.1016/0033-5894(80)90047-2

11. M. L. Bender, E. Burgess, R. B. Alley, B. Barnett, G. D. Clow, On the nature of the dirty ice at the bottom of the GISP2 ice core. Earth Planet. Sci. Lett. 299, 466-473 (2010). doi:10.1016/j.epsl.2010.09.033

12. E. Willerslev, E. Cappellini, W. Boomsma, R. Nielsen, M. B. Hebsgaard, T. B. Brand, M. Hofreiter, M. Bunce, H. N. Poinar, D. Dahl-Jensen, S. Johnsen, J. P. Steffensen, O. Bennike, J. L. Schwenninger, R. Nathan, S. Armitage, C. J. de Hoog, V. Alfimov, M. Christl, J. Beer, R. Muscheler, J. Barker, M. Sharp, K. E. Penkman, J. Haile, P. Taberlet, M. T. Gilbert, A. Casoli, E. Campani, M. J. Collins, Ancient biomolecules from deep ice cores reveal a forested southern Greenland. Science 317, 111-114 (2007). doi:10.1126/science.1141758 Medline

13. R. Souchez, J. Jouzel, A. Landais, J. Chappellaz, R. Lorrain, J.-L. Tison, Gas isotopes in ice reveal a vegetated central Greenland during ice sheet invasion. Geophys. Res. Lett. 33, L24503 (2006). doi:10.1029/2006GL028424

14. M. Stuiver, P. M. Grootes, GISP2 oxygen isotope ratios. Quat. Res. 53, 277 284 (2000). doi:10.1006/qres.2000.2127

15. A. J. Gow, D. A. Meese, R. B. Alley, J. J. Fitzpatrick, S. Anandakrishnan, G. A. Woods, B. C. Elder, Physical and structural properties of the Greenland Ice Sheet Project 2 ice core: A review. J. Geophys. Res. 102, 26559 (1997). doi:10.1029/97JC00165

16. A. J. Gow, D. A. Meese, Nature of basal debris in the GISP 2 and Byrd ice cores and its relevance to bed processes. Ann. Glaciol. 22, 134 (1996).

17. D. Weis, D. Demaiffe, R. Souchez, A. J. Gow, D. A. Meese, Ice sheet development in Central Greenland: implications from the $\mathrm{Nd}, \mathrm{Sr}$ and $\mathrm{Pb}$ isotopic compositions of basal material. Earth Planet. Sci. Lett. 150, 161-169 (1997). doi:10.1016/S0012-821X(97)00073-3

18. M. Suwa, J. C. von Fischer, M. L. Bender, A. Landais, E. J. Brook, Chronology reconstruction for the disturbed bottom section of the GISP2 and the GRIP ice cores: Implications for Termination II in Greenland. J. Geophys. Res. 111, D02101 (2006). doi:10.1029/2005JD006032

19. R. Souchez, J.-L. Tison, R. Lorrain, M. Lemmens, L. Janssens, M. Stievenard, J. Jouzel, A. Sveinbjörnsdottir, S. J. Johnsen, Stable isotopes in the basal silty ice preserved in the Greenland Ice Sheet at Summit; environmental implications. Geophys. Res. Lett. 21, 693-696 (1994). doi:10.1029/94GL00641

20. P. Huybrechts, Basal temperature conditions of the Greenland ice sheet during the glacial cycles. Ann. Glaciol. 23, 226 (1995).

21. J. A. Graly, P. R. Bierman, L. J. Reusser, M. J. Pavich, Meteoric ${ }^{10} \mathrm{Be}$ in soil profiles-a global meta-analysis. Geochim. Cosmochim. Acta 74, 6814-6829 (2010). doi:10.1016/j.gca.2010.08.036

22. T. D. Hamilton, "Surficial geology of the Dalton Highway (ItkillikSagavanirktok rivers) area, southern Arctic foothills, Alaska" (2003); www.dggs.alaska.gov/pubs/id/7191.

23. I. Callesen, K. Raulund-Rasmussen, C. J. Westman, L. Tau-Strand, Nitrogen pools and C:N ratios in well-drained Nordic forest soils related to climate and soil texture. Boreal Environment Research (2007); http://curis.ku.dk/ws/files/11055152/fulltext.pdf.

24. G. Hugelius, P. Kuhry, C. Tarnocai, T. Virtanen, Soil organic carbon pools in a periglacial landscape: A case study from the central Canadian arctic. Permafr. Periglac. Process. 21, 16-29 (2010). doi:10.1002/ppp.677

25. R. C. Finkel, K. Nishiizumi, Beryllium 10 concentrations in the Greenland Ice Sheet Project 2 ice core from 3-40 ka. J. Geophys. Res. 102, 26699 (1997). doi:10.1029/97JC01282
26. K. A. Refsnider, G. H. Miller, Ice-sheet erosion and the stripping of Tertiary regolith from Baffin Island, eastern Canadian Arctic. Quat. Sci. Rev. 67, 176189 (2013). doi:10.1016/j.quascirev.2013.01.010

27. L. Lisiecki, M. Raymo, A Pliocene-Pleistocene stack of 57 globally distributed benthic $\delta^{18} \mathrm{O}$ records. Paleoceanography 20, PA1003 (2005).

28. B. Heisinger et al., Production of selected cosmogenic radionuclides by muons. Geochim. Cosmochim. Acta 66, A558 (2002).

29. K. Nishiizumi et al., In situ produced cosmogenic nuclides in GISP2 rock core from Greenland summit. EOS 77, OS41B (1996).

30. K. M. Cuffey, H. Conway, A. M. Gades, B. Hallet, R. Lorrain, J. P. Severinghaus, E. J. Steig, B. Vaughn, J. W. C. White, Entrainment at cold glacier beds. Geology 28, 351 (2000). doi:10.1130/00917613(2000)28<351:EACGB >2.0.CO;2

31. J. Stone, A rapid fusion method for separation of beryllium-10 from soils and silicates. Geochim. Cosmochim. Acta 62, 555-561 (1998). doi:10.1016/S0016-7037(97)00340-2

32. D. H. Rood, T. A. Brown, R. C. Finkel, T. P. Guilderson, Poisson and nonPoisson uncertainty estimations of ${ }^{10} \mathrm{Be} /{ }^{9} \mathrm{Be}$ measurements at LLNL-CAMS. Nucl. Instrum. Methods B 294, 426-429 (2013). doi:10.1016/..nimb.2012.08.039

33. D. H. Rood, S. Hall, T. P. Guilderson, R. C. Finkel, T. A. Brown, Challenges and opportunities in high-precision ${ }^{10} \mathrm{Be}$ measurements at CAMS. Nucl. Instrum. Methods B 268, 730-732 (2010). doi:10.1016/j.nimb.2009.10.016

Acknowledgments: Supported by NSF grants ARC1023191 (P.R.B.) and ARC0713956 (P.R.B. and T.A.N.). Alaska soil collection and preparation were supported by NSF grants ARC0806394 and ARC0806399. P.R.B. analyzed the data and wrote the first draft of the manuscript; L.B.C. extracted the ${ }^{10} \mathrm{Be}$ and prepared final drafts of the figures; J.A.G. interpreted the ${ }^{10} \mathrm{Be}$ data; T.A.N. provided glaciological expertise; B.C. provided the Alaskan samples and context for their interpretation; D.H.R. made the accelerator mass spectrometry measurements; A.L. made and interpreted the OC and TN measurements; and all authors read and edited multiple versions of the manuscript. The data reported in this paper are tabulated in the supplementary materials.

\section{Supplementary Materials}

www.sciencemag.org/cgi/content/full/science.1249047/DC1

Materials and Methods

Tables $\mathrm{S} 1$ to $\mathrm{S} 3$

References (31-33)

27 November 2013; accepted 28 March 2014

Published online 17 April 2014

10.1126/science. 1249047 


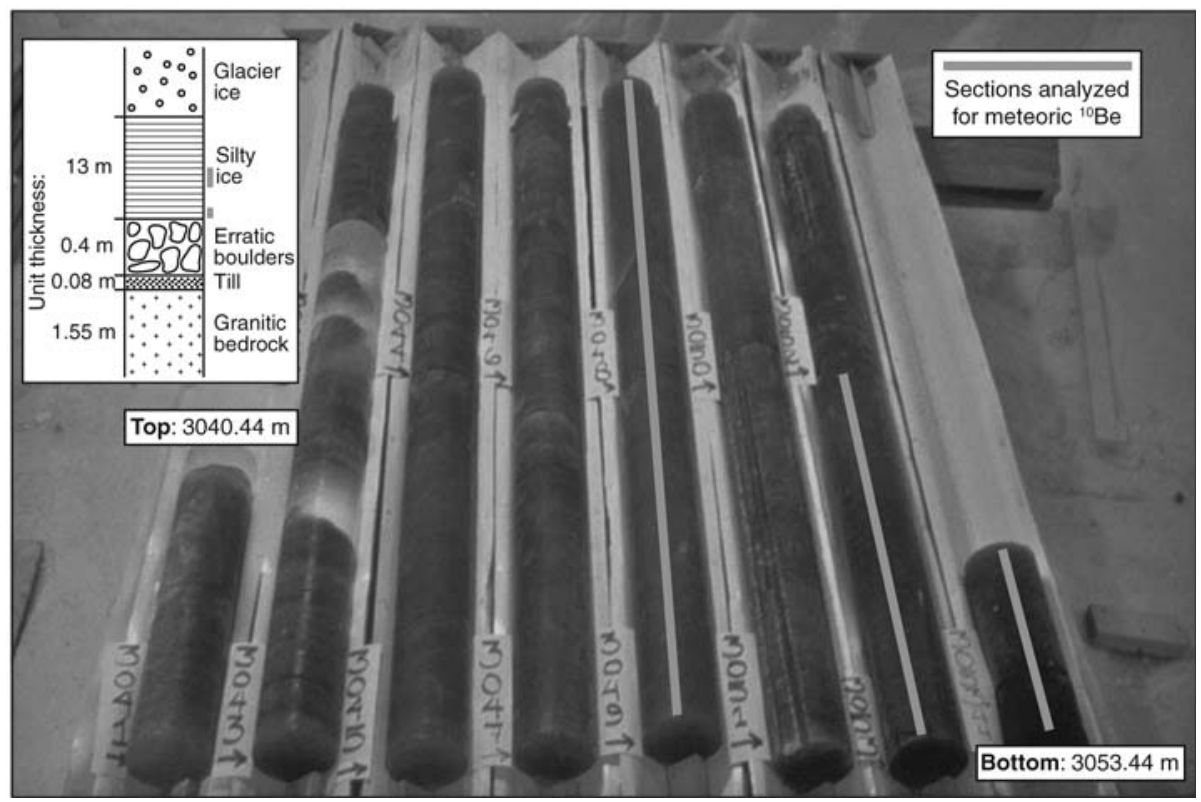

Fig. 1. Photograph of GISP2 ice core silty ice zone; the inset shows core stratigraphy (15). Thick gray lines indicate intervals of the ice core that were analyzed for meteoric ${ }^{10} \mathrm{Be}, \mathrm{OC}$, and TN. Core depth shown in meters by labels. Image from NOAA. 

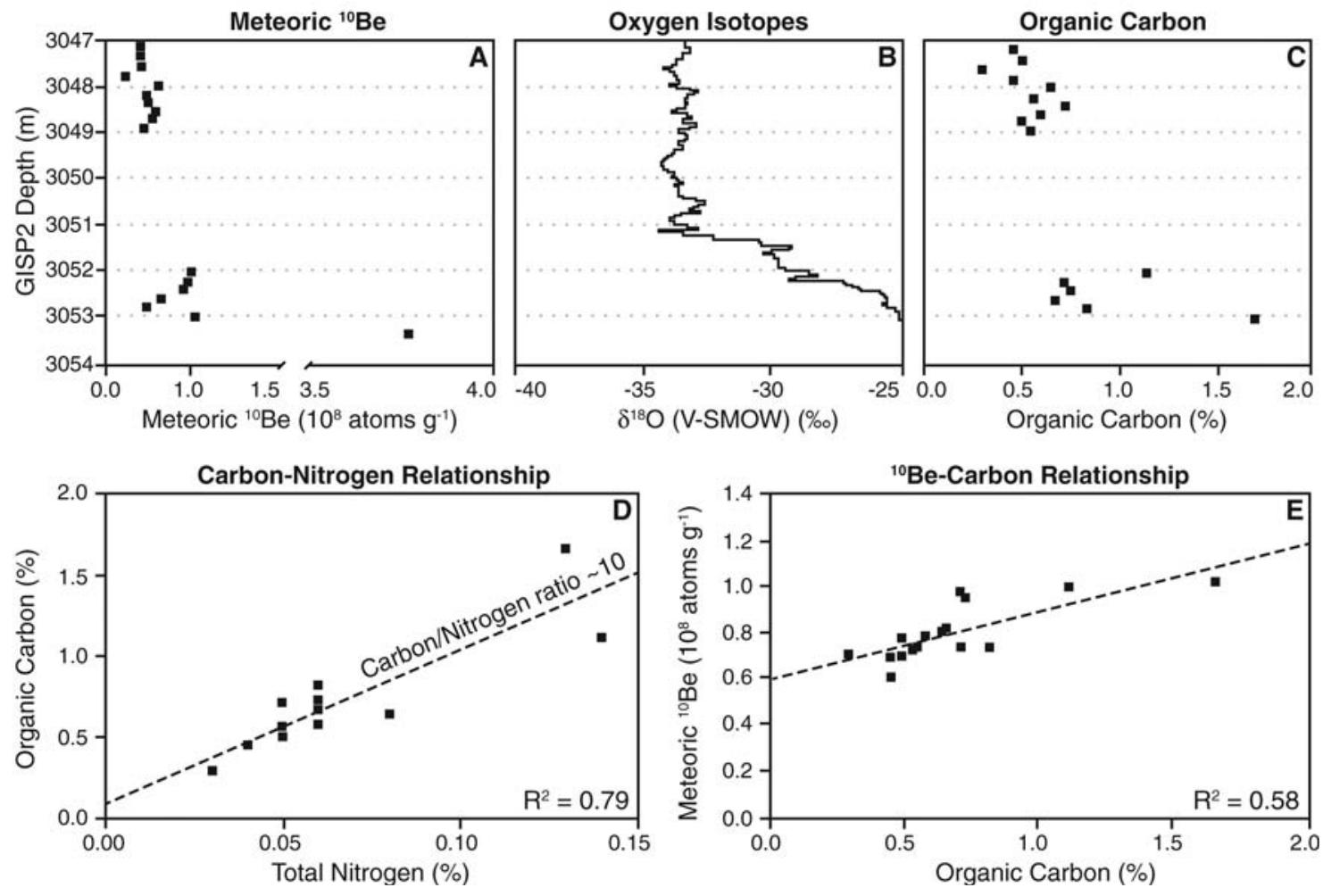

Fig. 2. Geochemical and isotopic data for GISP2 basal silty ice. (A) Meteoric ${ }^{10} \mathrm{Be}$ concentration of silt with core depth; horizontal axis has gap and variable scaling to allow plotting of the high-concentration lowermost sample. (B) Water oxygen isotopes in ice (14). (C) Organic carbon (OC) measured in acidified silt. (D) Organic carbon/total nitrogen ratio measured in acidified silt. (E) Positive linear relationship between organic carbon and meteoric ${ }^{10} \mathrm{Be}$ in silt samples. Data in table S1. 

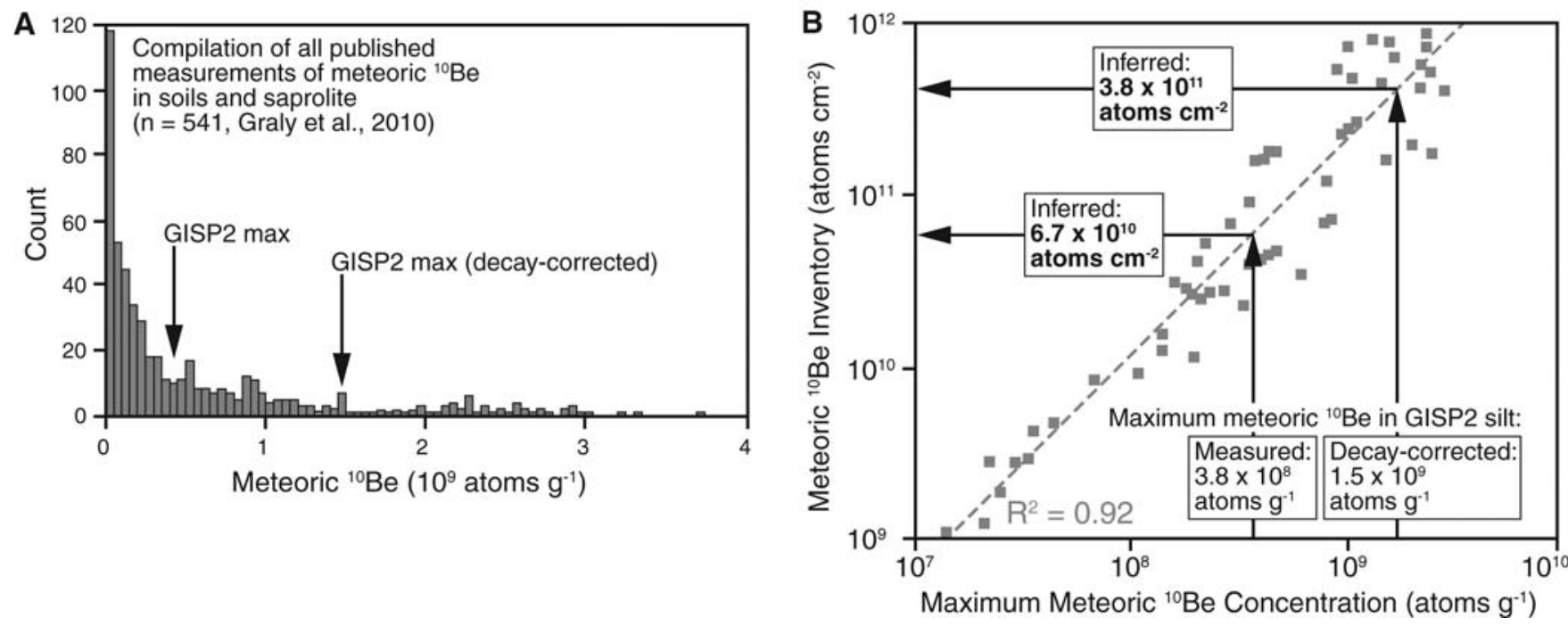

Fig. 3. GISP2 silt contains high concentrations of meteoric ${ }^{10} \mathrm{Be}$. (A) Histogram of 541 measurements of meteoric ${ }^{10} \mathrm{Be}$ made in soils (21) with maximum meteoric ${ }^{10} \mathrm{Be}$ measured in GISP2 silt and decay-corrected concentration assuming burial for two half-lives of ${ }^{10} \mathrm{Be}\left(\sim 2.7\right.$ million years). (B) Maximum meteoric ${ }^{10} \mathrm{Be}$ concentrations in soil profiles are well correlated to soil meteoric ${ }^{10} \mathrm{Be}$ inventories (21). Using measured and decay-corrected maximum meteoric ${ }^{10} \mathrm{Be}$ concentrations in GISP2 silty ice suggests that meteoric ${ }^{10} \mathrm{Be}$ inventory in pre-GIS soil was at least $6.7 \times 10^{10}$ atoms cm${ }^{-2}$ and likely $3.8 \times 10^{11}$ atoms cm${ }^{-2}$.

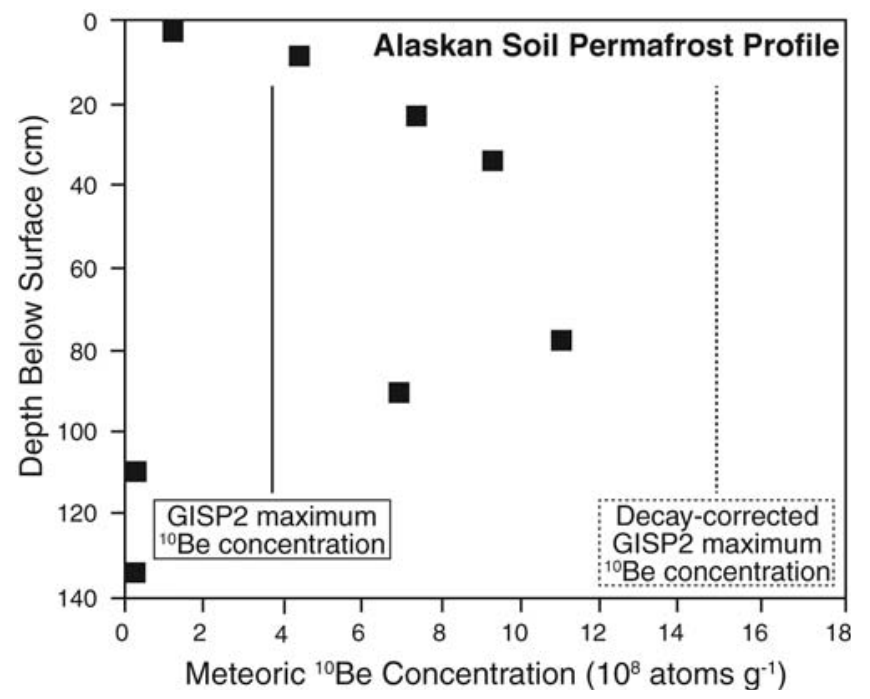

Fig. 4. Depth profile of meteoric ${ }^{10} \mathrm{Be}$ measured in a stable soil profile developed on glacial sediment deposited $>150,000$ years ago, North Slope, Alaska. Prominent subsurface bulge is indicative of a stable soil profile (21). Maximum measured and decay-corrected concentrations of meteoric ${ }^{10} \mathrm{Be}$ measured in GISP2 silt are overlain. Data in table S2. 